\title{
Exclusion of the Polyarthra from Harpacticoida and its reallocation as an underived branch of the Copepoda (Arthropoda, Crustacea)
}

\author{
Hans-Uwe Dahms \\ Hong Kong University of Science and Technology/ Dept. Biology - Coastal Marine Lab/ \\ Kowloon - Clearwater Bay/ Hong Kong/SAR China. \\ e-mail:hansd@ust.hk
}

\begin{abstract}
There is no reasonable autapomorphy, either from the naupliar or the adult organization, which justifies a monophylum Harpacticoida (sensu Lang, 1948). This implies a paraphyletic situation of this taxon, comprising two independent monophyletic taxa, the Polyarthra and the Oligoarthra. To solve this problem, the present study will provide justifying arguments for the exclusion of the taxon Polyarthra from the Harpacticoida, which then is exclusively represented by the monophylum Oligoarthra. When Polyarthra are excluded from the Harpacticoida, than Oligoarthra share the following naupliar synapomorphies: postmaxillar limbs widely spaced, antennal coxa with strong gnathobase, antennal endopodite elongate, mandibular endopodite an elongate process. Based on naupliar characters, Polyarthra are allocated as an underived taxon of the Copepoda, sharing with all other Copepoda the following naupliar characters: antennule 5segmented, antennal exopodal segments increase from 6 at $\mathrm{N}$ I to a final number of 9 at $\mathrm{N}$ IV, antennal endopodite is 1-segmented, maxilla absent, swimming performance and life history, dorsocaudal process, antennule segment homologues, larger number of segments in naupliar antennal endo- and exopodites.
\end{abstract}

KEYWORDS: nauplii, development, phylogenetic systematics, $\beta$-systematics, evolution, Polyarthra, Harpacticoida, Copepoda.

\section{Исключение группы Polyarthra из Harpacticoida и выделение ее в примитивную ветвь Copepoda (Arthropoda, Crustacea)}

\author{
Г.-У. Дамс \\ Hong Kong University of Science and Technology/ Dept. Biology - Coastal Marine Lab/ \\ Kowloon - Clearwater Bay/ Hong Kong/SAR China. \\ e-mail:hansd@ust.hk \\ РЕЗЮМЕ: Особенности организации ни науплиальных, ни, в такой же мере, взрос- \\ лых стадий не позволяют выделить надежные аутапоморфии, которые бы подтвер- \\ ждали монофилетичность Harpacticoida (sensu Lang, 1948). Это указывает на парафи- \\ летичность данного таксона, включающего две независимые монофилетические \\ группы: Polyarthra и Oligoarthra. Чтобы решить проблему, в данной работе приведе- \\ ны доказательства, указывающие на необходимость исключения Polyarthra из отряда \\ Harpacticoida, который в таком случае будет представлен исключительно монофиле-
}


тической группой Oligoarthra. При исключении Polyarthra из Harpacticoida науплисы Oligoarthra характеризуется следующими синапоморфными признаками: постмаксиллярные конечности расставлены широко, кокса антенн с хорошо развитой гнатобазой, эндоподит антенн удлинен, эндоподит мандибул имеет удлиненный вырост. На основании признаков науплиальных стадий Polyarthra выделяется в примитивный таксон Copepoda, науплиусы которого характеризуются, как и у всех других Copepoda, следующими признаками: антеннулы пятичлениковые, членение экзоподита антенн возрастает с 6 на стадии N I (науплиус первой стадии) до 9 на науплиальной стадии N VI, эндоподит антенн одночлениковый, максилла отсутствует, плавательное движение и жизненный цикл, дорзокаудальный вырост, гомология члеников антеннул, большое число члеников экзоподита и эндоподита антенн.

КЛЮЧЕВЫЕ СЛОВА: Науплисы, развитие, филогенетика, Љ-систематика, эволюция, Polyarthra, Harpacticoida, Copepoda.

\section{Introduction}

In organisms with larval development, both, early and late developmental stages show characters of the same genotype. However, in most cases only the adults have so far been used for the reconstruction of phylogenetic relationships, although larvae may provide a rich source of additional morphological, behavioural, and ecological characters. Evidence from postembryonic stages should complement that gained from adult characters for an individual exhibits different and significant characters at all phases of its ontogeny which can be used as speciesspecific character patterns of evolutionary species (Ax, 1987). Often a larva is as valuable for phylogenetic and taxonomic investigations as the adult and much more valuable in cases where the adult is highly specialized and recently has been altered. In phylogenetic investigations an uncritical use of larval characters is just as unadmissible as a similar use of the characters of the adults (Jägersten, 1972).

Larval characters have been used for phylogenetic studies of Crustacea. Schminke (1981) demonstrated the origin of Bathynellacea by neotenous processes from a zoea-like ancestor. Gurney (1942) showed that larval characters are useful for separating decapods at various taxonomic categories. Within the Paguroidea (Anomura), the widely accepted recognition of the
Diogenidae and the Parapaguridae as distinct families resulted largely from considerations of larval characters (Williamson, 1982). Rice (1986) gave an outline of the evidence drawn from the zoea-stage for the phylogeny of the Brachyura. Dahms (1990) has demonstrated the usefulness of naupliar characters in phylogenetic hypotheses among the Harpacticoida. Walossek (1993) and Maas et al. (2003) demonstrated that larval characters are also useful in the reconstruction of the phylogeny of Crustacea considering also or exclusively fossil taxa. Several other colleagues have used naupliar characters for phylogenetic considerations and their results will be discussed where appropriate throughout this study ( $c f$. Ferrari, Ivanenko, 2001).

Polyarthran harpacticoid nauplii differ strikingly in a number of characters from those of the Oligoarthra and they do not share a single naupliar character with them. The monophyletic status of the Harpacticoida, hitherto comprising Polyarthra and Oligoarthra, is therefore questioned. The present contribution aims to provide phylogenetic inferences for the reallocation of the Polyarthra, and will use naupliar characters for phylogenetic reconsiderations. Consequences for the reallocation of the Polyarthra will be discussed in the light of the evolution of the Maxillopoda. 


\section{Material and methods}

Nauplii were reared from individual females to ensure reliable species identification. The original ovigerous females which provided the developmental stages were collected from various areas (Dahms, 1990). Substrate from field samples was stirred in a beaker, and subsequently decanted over a screen ( $100 \mu \mathrm{m}$ mesh-size $)$. The residue containing adults was rinsed into smaller bowls for transport to the laboratory. The developmental stages used were the offspring exclusively of single-female cultures. Female identity was determined after successful culturing. For culturing procedures see Dahms (1990).

Stages were selected individually under a dissecting microscope and fixed in 5\% buffered formaldehyde and embedded in W 15 (C. Zeiss Company). This clarifies nonexuvial material within a few weeks and provides information on hidden posterior structures when observed by phase-contrast. Unfortunately, the natural colour of nauplii, e.g. colour and shape of the red nauplius-eye, was lost quite rapidly and the eye is, therefore, not figured. Nauplii, exuviae and copepodids were mounted whole, and broken glass-fibres were added to prevent compression and to facilitate specimen movement to allow inspection from all sides. Abnormalities occasionally were observed but not been figured. Body lengths were measured from the anterior to the posterior end of the naupliar body; body width is given as the widest part of the nauplius. Drawings were made from individual specimens; others were checked for variability. The naupliussensu stricto is an orthonauplius (with 3 limb-bearing segments). If a nauplius has developed another pair of limbs. Naupliar somites are difficult to determine], it is called metanauplius. The general term "nauplius" refers in the present contribution to all larval stages throughout the naupliar phase (being characterized e.g. by the presence of antennal gnathobases).

Characters were assembled from personal observations and various sources in the literature: Cephalocarida (Sanders, 1963 a,b); Branchiopoda (Walossek, 1993; Olesen, 1999); Mystacocarida (Delamare Deboutteville, 1954;
Olesen, 2001); Ostracoda (Keslingm, 1951); Thecostraca (Bassindale, 1936; Itô, 1986a,b; Grygier, 1987a,b); Harpacticoida(Dahms, 1990, 1991); Cyclopoida(Koga, 1984; Dahms, Fernando, 1992; Ferrari, 2000; Ferrari, Ivanenko, 2001); Poecilostomatoida (Izawa, 1986); and Calanoida (Song, Jinchuan, 1990; Dahms, Fernando, 1993). The following contributions were used for general information about crustacean nauplii or maxillopodan phylogeny: Koga (1984), Björnberg (1986), Izawa (1986), Schram (1986), Grygier (1987a,b), and Boxshall and Huys (1989). Nauplii are defined as those ontogenetic stages which still bear the antennal enditic process, while metanauplii have more than the 3 appendages of A1, A2, and Md developed, if only as limb buds.

\section{Abbreviations used:}

A1 - first antenna (=antennule); A2 - second antenna (=antenna); Abd - abdomen; Ae - aesthetasc; CI, II - copepodid I, II etc.; Cs - cephalic shield; Dcsp - dorsocaudal spine dorsal to anus; End - endite (setiferous lobes of limb corm); Enp — endopodite; Exp exopodite; Cur — caudal ramus; La — labrum; $\mathrm{M}$ - mouth; Md - mandible; Msp - masticatory spine of mandibular basipod; Mx1 first maxilla; $\mathrm{Mx} 2$ - second maxilla; NI, II nauplius I, II etc.; $\mathrm{Ne}$ - nauplius eye; Pgn paragnaths; Som (Som 4) — somite (the 4th somite); Set — seta(e); Setat — setation; Thp thoracopods (trunk legs); Ths - Thoracic somites; Vcp - ventrocaudal process (pair of processes at ventrocaudal margin of telson).

\section{Обозначения:}

А1 - первая антенна (=антеннула); А2 - вторая антенна (=антенна); Abd - абдомен; Ае - эстетаск; CI, II - копеподитнаястадия I, II и т.д.; Cs - головной щит; Dcsp - дорзокаудальный шип над анусом; End - эндит (щетинистые лопасти в основании конечностей); Enp - эндоподит; Exp - экзоподит; Cur - каудальная ветвь; $\mathrm{La}$ - лабрум; M — рот; Md - мандибула; Msp - жевательный шип базиподита мандибул; Мх1 - первоя максилла; Мх2 - вто- 


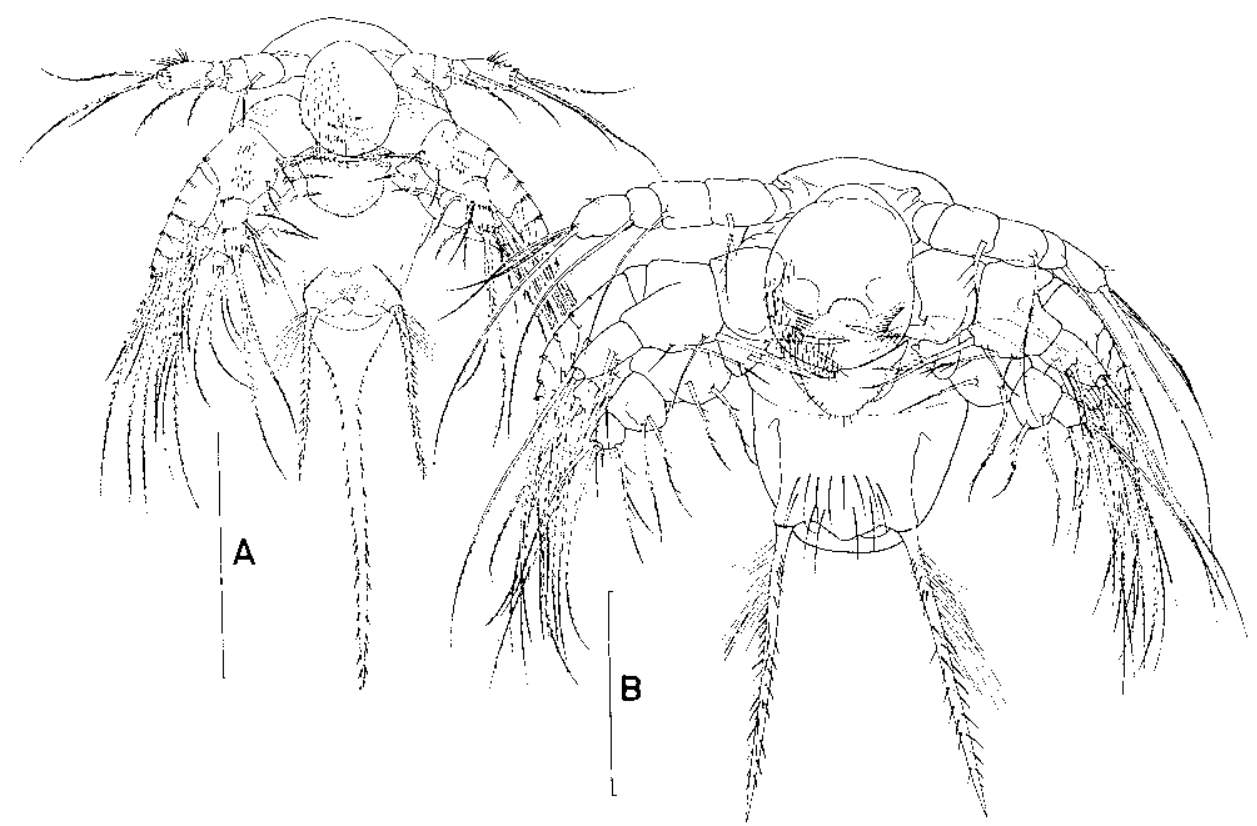

Fig. 1. First naupliar stages (NI) of Polyarthra.

(A) Longipedia minor (Longipediidae). (B) Canuella perplexa (Canuellidae). Scale bars $50 \mu \mathrm{m}$ (after Dahms, 1991). Рис. 1. Науплисы первой стадии (NI) Polyarthra.

(A) Longipedia minor (Longipediidae). (B) Canuella perplexa (Canuellidae). Масштаб 50 мкм (по Dahms, 1991).

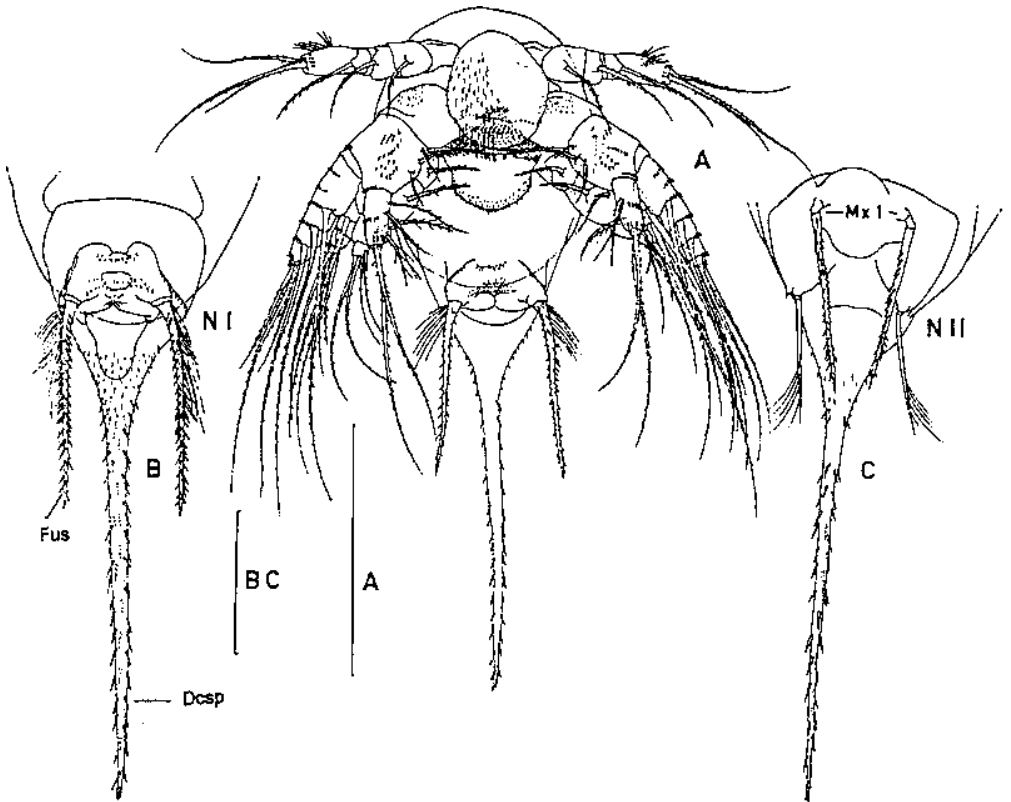

Fig. 2. Structural changes in Longipedia minor.

Habitus of NI - scale bar $100 \mu \mathrm{m}$ (A). Abdomen of NI (B) and NII (C) in ventral view; development of maxillule

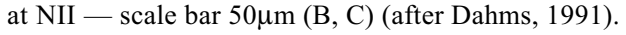

Рис. 2. Изменения в строении Longipedia minor.

Общий вид стадии NI, масштаб $100 \mathrm{mkm}$ (А). Абдомен на стадиях NI (B) и NII (C), вид снизу; развитие максиллул на стадии NII; масштаб 50 мкм (B, C) (по Dahms, 1991). 


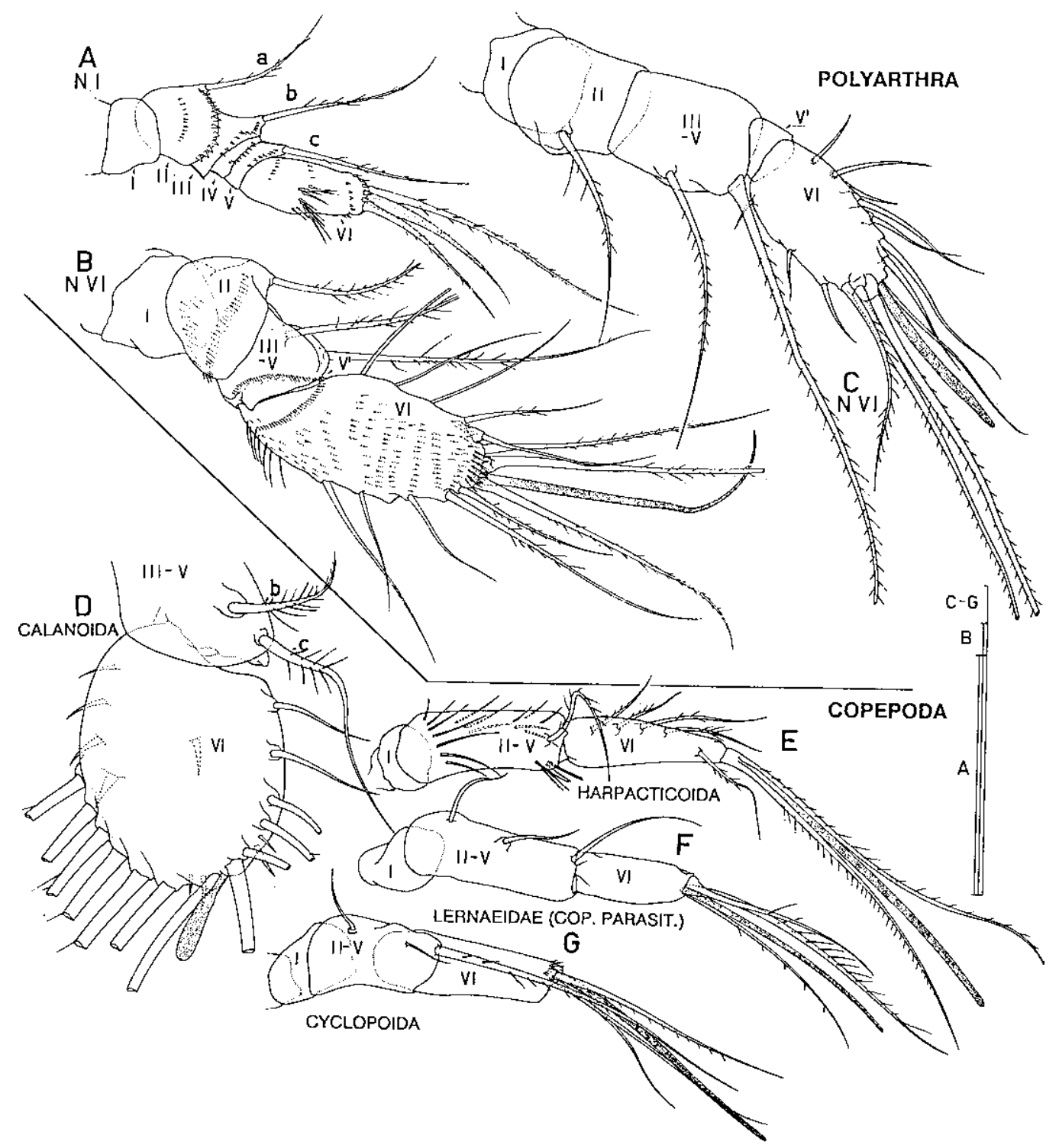

Fig. 3. Antennule segment homologues among copepod taxa.

(A, B) Longipedia minor at NI (A) and NII (B); (C) Canuella perplexa at NVI; (D) representative of Diaptomidae at NVI; (E) Euterpina acutifrons at NVI; (F) representative of Lernaeidae at NVI. Scale bars $50 \mu \mathrm{m}$.

Рис. 3. Гомология члеников антеннул копепод разных таксонов.

(A, B) Longipedia minor на стадиях NI (A) и NII (B); (C) Canuella perplexa на стадии NVI; (D) представитель Diaptomidae на стадии NVI; (E) Euterpina acutifrons на стадии NVI; (F) представитель Lernaeidae на стадии NVI. Масштаб 50 мкм.

рая максилла; NI, II - науплиальная стадия I, II и т.д.; Ne - науплиальный глаз; Pgn парагнаты; Som (Som 4) - сегмент (4-й сегмент); Set - щетинка(и); Setat — вооруже- ние; Thp — торакоподы (грудные ноги); Ths - грудной сегмент (= сомит); Vcp вентрокаудальный вырост (пара выростов на вентрокаудальном крае тельсона). 


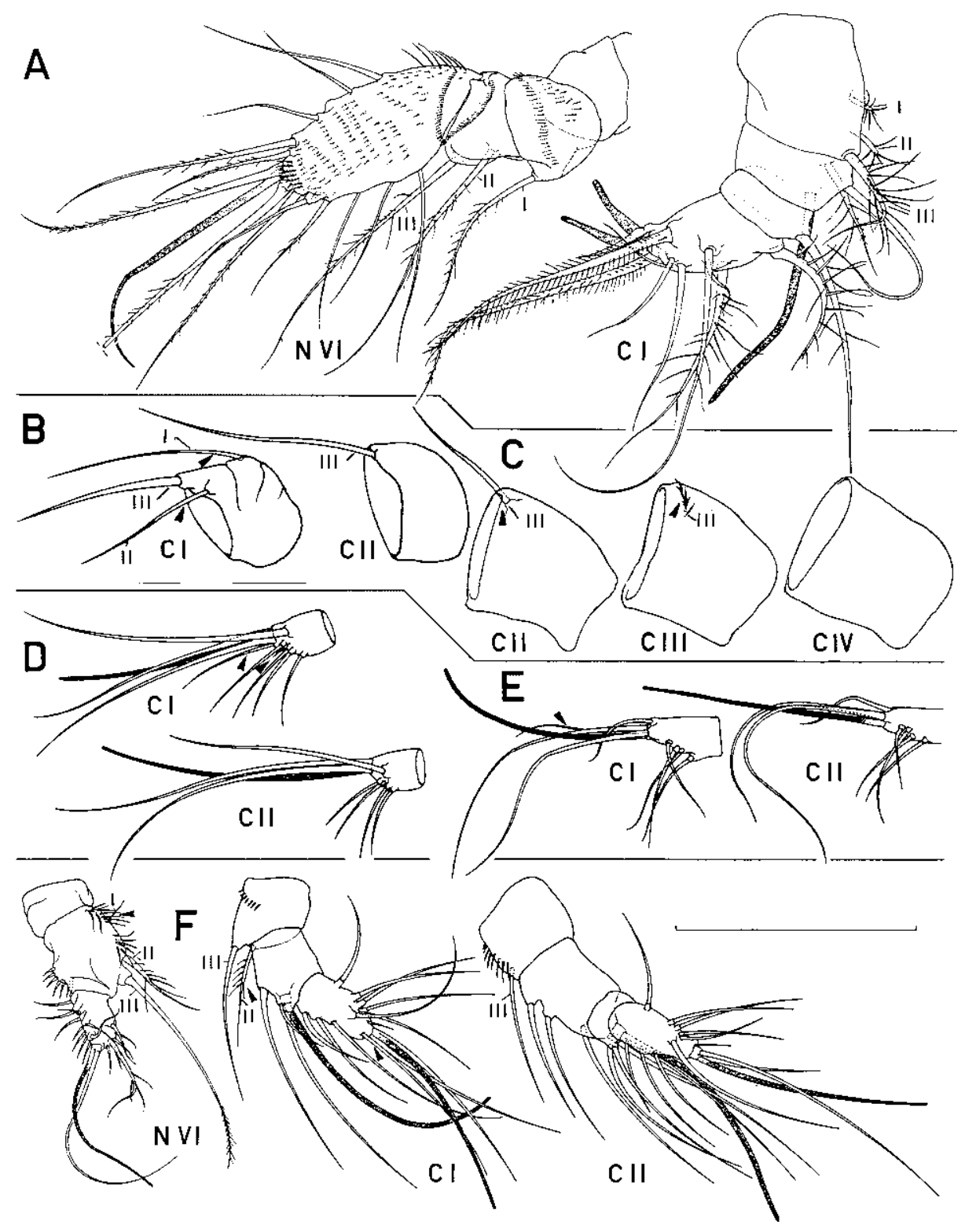

Fig. 4. Antennule development in Polyarthra and Oligoarthra.

(A) Longipedia minor at NVI and CI. (B) First segment of Ectinosoma melaniceps at CI and CII; (C) First segment of Macrosetella gracilis at CII, CIII and CIV. (D) Distal segment of Thalestris longimana at CI and CII. (E) Distal segment of Tegastes clausi at CI and CII. (F) Heterolaophonte minuta at NVI, CI and CII (I-III, a-c: indicating the three setae of the 2nd segment of a 3-segmented oligoarthran naupliar antennule; arrowheads in B-F pointing at structures which are reduced in the subsequent stages). Scale bar $50 \mu \mathrm{m}$ (after Dahms, 1991).

Рис. 4. Развитие антеннул в Polyarthra и Oligoarthra.

(A) Longipedia minor на стадиях NVI и CI. (B) Первый членик Ectinosoma melaniceps на стадиях CI и CII; (C) Первые членик Macrosetella gracilis на стадиях CII, CIII и CIV. (D) Дистальный членик Thalestris longimana на стадиях CI и CII. (Е) Дистальный членикTegastes clausi на стадиях CI и CII. (F)Heterolaophonte minuta на стадиях NVI, CI и CII (I-III, a-c: указывают на три щетинки на 2-м членике трехчлениковых антеннул науплисов Oligoarthra; стрелки на рис. B-F указывают на структуры, редуцирующиеся на более поздних стадиях). Масштаб 50 мкм (по Dahms, 1991). 
A phylogenetic problem - the paraphyletic status of the Harpacticoida and the unsettled position of the Polyarthra.

Nauplii of the two only polyarthran families Longipediidae and Canuellidae, usingLongipedia minor and Canuella perplexa as examples, figured at NI (Fig. 1) appear quite dissimilar. This is mainly due to the long caudal spine of Longipedia causing the pear-shaped body form of the nauplii. However, the two families show several structural as well as meristic similarities, some of which are assumed to be autapomorphic on the basis of outgroup comparison suggesting the monophyletic status of both families, which have a sister taxon relationship with each other - see below. As for the lifecycle of the Polyarthra - both taxa show a habitat transition from substrate bound adults to planktic nauplii (Dahms, 2000). Here, I will enumerate only meristic synapomorphies for polyarthran taxa (see also Dahms, 1990), they:

1) bear 5-segmented antennules (from NIIVI) with the same number and pattern of setae from NI-III (Figs. 1, 2);

2) have 6-segmented antennal exopodites that increase their segment number by 3 at NIV, when the final number of 9 segments with an identical setal pattern is reached (Fig. 5);

3) have a similar structure of the postmandibular appendages and the same stage at which they appear (see below);

4) have a pair of caudal setae at NI with specific spinular ornamentation and reduction of size at NII (Fig. 6)

5 ) have 6 caudal setae on either side at NVI (Fig. 6).

Therefore, the Polyarthra (i.e. Longipediidae and Canuellidae, Figs. 1-7) share a number of naupliarautapomorphies characterizing them as a monophylum. Polyarthran nauplii differ strikingly in a number of characters from the nauplii of Oligoarthra and they do not share a single naupliar character with the Oligoarthra (as for the autapomorphies of the Oligoarthra see below). The monophyletic status of the Harpacticoida, comprising Polyarthra and Oligoarthra until now, is therefore questioned. All characters Polyarthra share with for instance the
Cyclopoida or the Calanoida are regarded as plesiomorphic. Otherwise, it appears that the naupliar characters of Polyarthra are the most plesiomorphic naupliar copepod characters compared to copepodan as well as to other maxillopodan taxa. Polyarthran naupliar characters also agree with those of other maxillopodan groups, especially with the Cirripedia.

If Polyarthra were excluded from the Harpacticoida, the remaining monophylumOligoarthra is characterized by the following four autapomorphies (illustrations are provided by Dahms, 1990, 2004):

1) Postmaxillar limbs widely spaced in later metanauplii: In Cephalocarida (Sanders, 1963a,b), Branchiopoda (Olesen, 1999), and Mystacocarida(Olesen, 2001) the postmaxillar appendages are separated medially, probably to provide space for a medial food grove where food is transported frontally. This character is not available from the Thecostraca for their lack of appendages caudal to the maxillules. Postmaxillar appendages are juxtaposed medially in Cyclopoida, Polyarthra and Calanoida, whereas they are widely spaced in the Oligoarthra. This positional peculiarity indicates a striking difference between copepod antennules to the second maxillae (= cephalic) and postmaxillary (= thoracic) appendages. As indicated from this plesiomorphic condition - taking non-thecostracan Maxillopoda as an outgroup, where the postmaxillar appendages of copepod nauplii are juxtaposed medially (also in Polyarthra), the position of these limbs becomes lateroventral among the Oligoarthra-Maxillipedasphalea (Lang, 1948), and even more widely spaced and laterally located among the Oligoarthra. However, limb buds of thoracopods 3-6 of presumed derived calanoids are located laterally (Ferrari, Steinberg, 1993; Ferrari, Markhaseva, 1996) relative to the ventral position of presumed older calanoids (Ferrari, 1985, 1996). Therefore, it is not unlikely that this character seems to have evolved independently several times.

2) Antennal coxa with strong gnathobase throughout the naupliar phase: Whereas the antennal coxa of all major copepod taxa consists of just an inner protuberance with some 


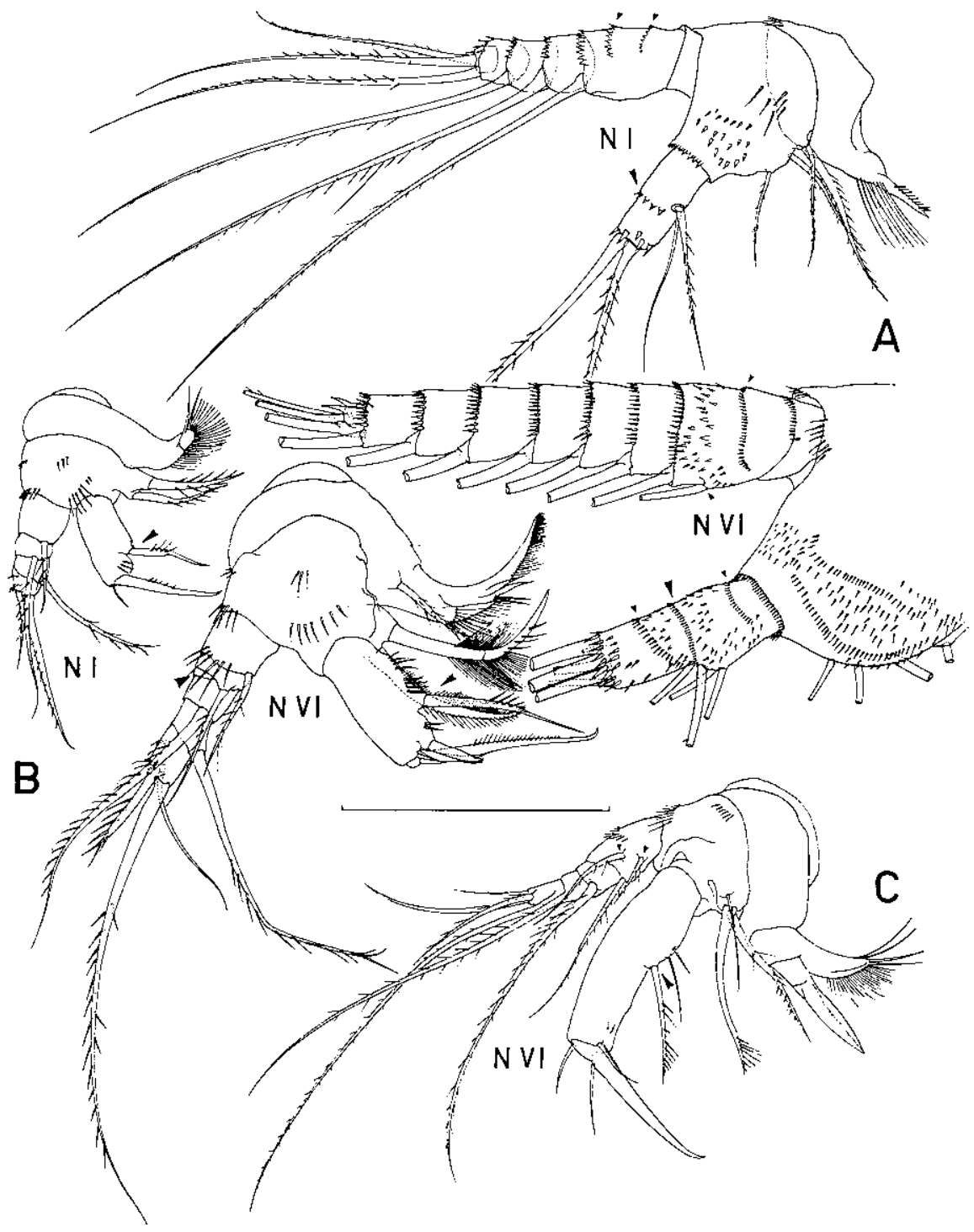

Fig. 5. Antennal development in the Harpacticoida. (A - Polyarthra; B, C - Oligoarthra.).

(A) Longipedia minor at NI and its basis, endopodite and exopodite at NVI; (B) Phyllognathopus viguieri at NI and NVI. (C) Scutellidium hippolytes at NVI (arrowheads pointing at structures which are indicative of former segment borders). Scale bar $50 \mu \mathrm{m}$ (after Dahms, 1991).

Рис. 5. Развитие антенн Harpacticoida. (А — Polyarthra; B, C - Oligoarthra.).

(A) Longipedia minor на стадии NI; базис, эндоподит и экзоподит на стадии NVI; (B) Phyllognathopus viguieri на стадиях NI и NVI. (C) Scutellidium hippolytes на стадии NVI (стрелка указывает на структуры, показывающие прежние границы члеников). Масштаб 50 мккм (по Dahms, 1991).

strong setal armature, there is a pronounced masticatory process already indicated at $\mathrm{NI}$ (see Fig. 5C), and this is strongly developed from NII onwards in the Oligoarthra.
3) Antennal endopodite elongate throughout the naupliar phase: The 1-segmented antennal endopodite is lobe-like otherwise in copepod taxa, whereas it is 1 -segmented and 
POECILOSTOMATOIDA

(A) Tegobomolochus nasicola

(after Izawa, 1986)
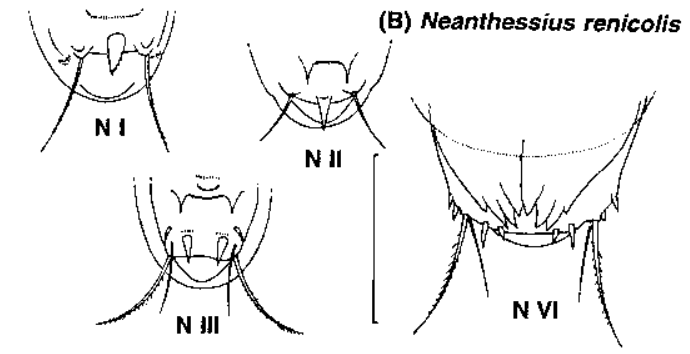

POLYARTHRA

(C) Longipedia minor

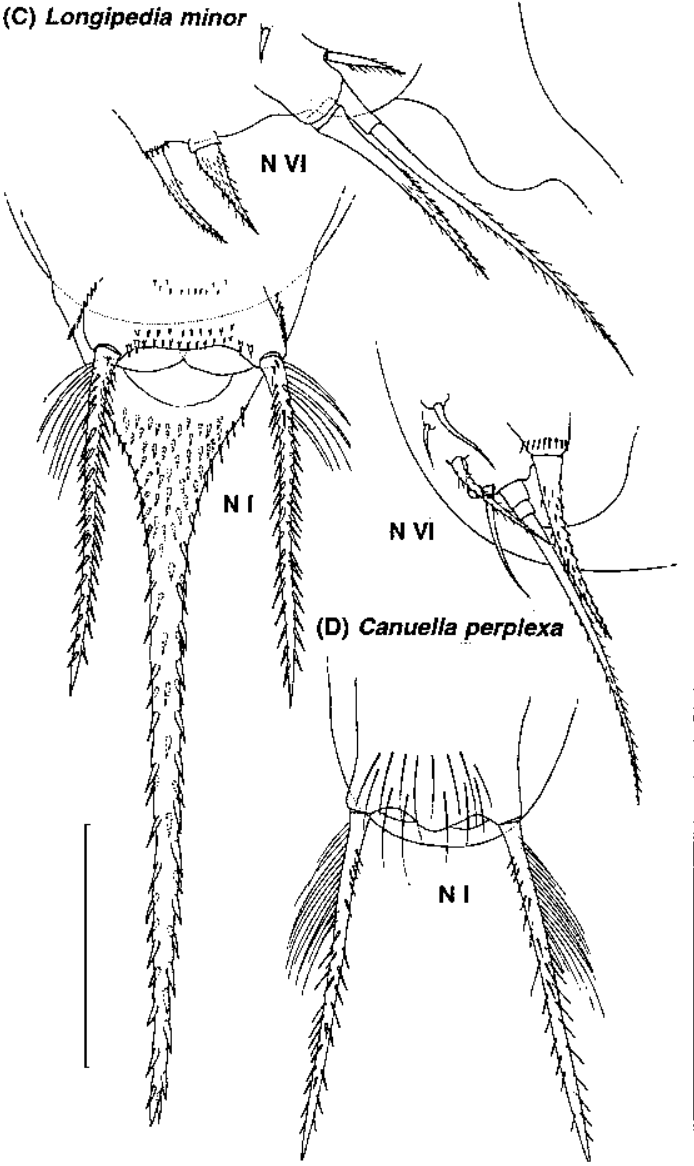

PODOPLEA

CYCLOPOIDA

(E) Mesocyclops edax
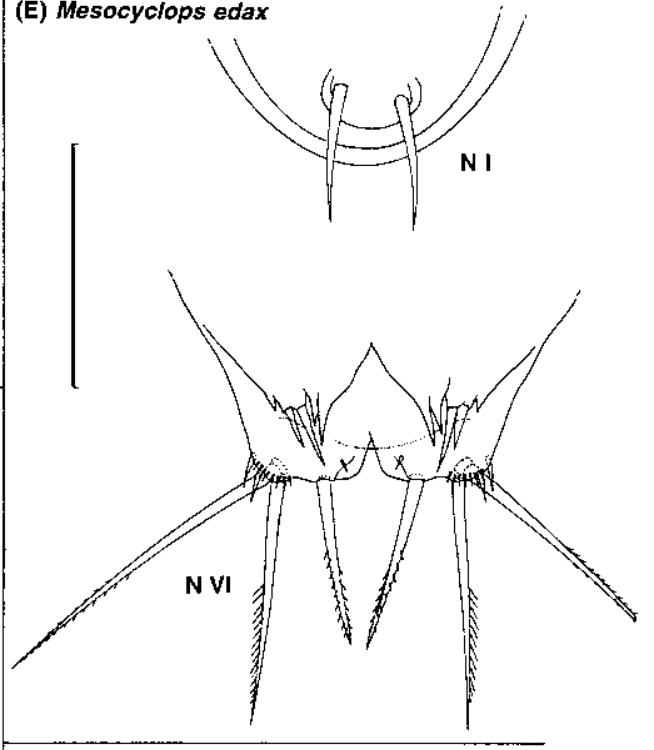

HARPACTICOIDA

(F) Phyllognathopus viguieri

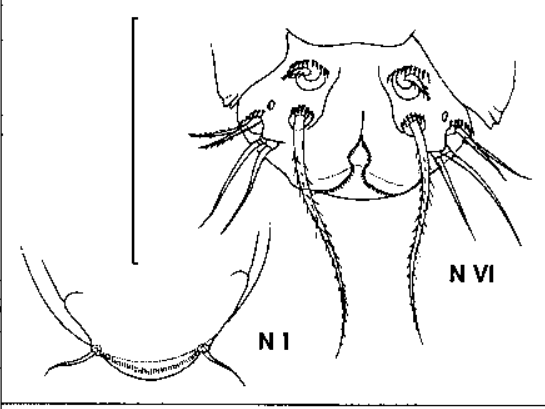

CALANOIDA

(G) Phyllodiaptomus annae

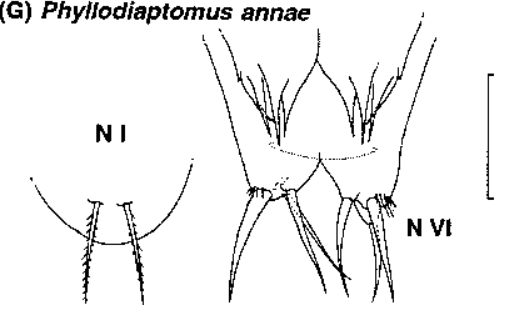

Fig. 6. Development of abdomen and caudal armature in copepod nauplii; showing a caudal process, or a symmetrical/asymmetrical abdomen. Only one prospective caudal ramus is shown for NVI of Longipedia minor (C) and Canuella perplexa (D). Scale bar $50 \mu \mathrm{m}$.

Рис. 6. Развитие абдомена и каудального вооружения у науплисов копепод; показаны каудальный вырост или симметричный/асимметричный абдомен. Для стадии NVILongipedia minor (C) иCanuella perplexa (D) показан только один зачаток каудальной ветви. Масштаб 50 мкм. 
becomes elongate in Oligoarthra. Its reduced state is apparent from the 1 to 4 setae situated at the inner margin midlength representing the armature of the remnant first of a former 2segmented endopodite.

4) Mandibular endopodite an elongate process: The endopodal process of the mandible is lobe-like and bears 4 or more setae usually of the same size at later stages in all major copepod taxa. In Oligoarthra there is an elongate, rectangular process with1 (Harpacticidae, Thalestridae, Metidae) or 2 stout spiniform setae terminally, besides some smaller setae (cf. Dahms, 1990).

If Polyarthra are excluded from the Harpacticoida (with the Oligoarthra as the only remaining taxon), a sister-group relationship of the Polyarthra with the Copepoda-Podoplea or a subset of this group is unlikely because Polyarthra share only a single rather unspecific naupliar character with the remaining podopleans (Podoplea, orthoand metanauplii are known from the Monstrilloida, Misophrioida, Cyclopoida, Poecilostomatoida, and Siphonostomatoida):

1)Mandibular endopodite 2-segmented: The mandibular endopodite is indistinctly 2 -segmented in Cephalocarida, 3-segmented in the Mystacocarida and Cirripedia, 1-segmented in Ascothoracida, and 2-segmented in "Facetotecta" and Podoplea. The mandibular endopodite is present in all representatives of the Polyarthra, Cyclopoida, Poecilostomatoida, Siphonostomatoida, Misophrioida. In gymnopleans one or more arthrodial membranes fail to form, resulting in a single segment. A 2-segmented condition is clearly present in the Polyarthra, but it is difficult to observe in some Cyclopoida and most Oligoarthra. In many representatives of Oligoarthra, also a reduction to a 1-segmented state or an "endopodal field", fused to the basis takes place (Dahms, 1990).

If, on the other hand, Polyarthra were kept as a sister-taxon of all the remainingCopepoda, the remaining taxa of the Copepoda share the following six naupliar synapomorphies (using other maxillopodan nauplii as an outgroup) ( $c f$. Dahms, 2004):

1) 3-segmented antennules throughout the naupliar phase: A 3-segmented antennule is pre- sent in nauplii of Cyclopoida, Oligoarthra, Calanoida and Notodelphyoida (Dudley, 1966) and in the Facetotecta (Itô, 1986b) throughout the naupliar phase but in no other maxillopodan taxon.

2) 6-segmented antennal exopodites in later naupliar stages: A maximum number of 6 segments for the antennal exopodite at later stages is characteristic for nauplii of the Calanoida and of free-living Cyclopoida (Gurney, 1932), but for no other maxillopodan group. Segment number is lower in other groups of the Copepoda, including the Oligoarthra.

3) Presence of the maxillae at later metanauplii: The presence of a maxilla is, however, not strong evidence because its absence in Polyarthra is a reduction which could have evolved several times independently.

4) 1-segmented antennal endopodites throughout the naupliar phase: The antennal endopodite throughout the naupliar phase is 2segmented in the Cephalocarida and in the Facetotecta, but 3-segmented in Mystacocarida, Cirripedia, and Ascothoracida of Thecostraca. Therefore, a 1-segmented naupliar antennal endopodite, which is present without exception among copepod nauplii, is a strong apomorphy for the Copepoda. The presence of one spinule row (or more in later naupliar stages) on this ramus of the polyarthran Longipedia minor $\mathrm{T}$. \& A. Scott, 1893 (Dahms, 1991), may indicate an ancestral 2-segmented state (or even 4-segmented state in later naupliar stages).

5) Legs 1, 2 present at NVI: The external appearance of the second and third thoracic appendages as limb buds at NVI in all major copepod taxa is a unique character compared to other crustacean nauplii ( $c f$. Walossek, 1993) and, provides a strong autapomorphy for the Copepoda. It is unlikely that a more posterior limb bud will be developed in copepod nauplii as proposed by Izawa (1987), who cited the presence of leg 3 at NVI in the descriptions of various authors. This pair of limbs belongs to the first copepodid, although it may become visible through the naupliar cuticle on the intermoult first copepodid ( $c f$. Dahms, 1992). Exceptions in the form of reductions are provided by certain Harpacticoida-Oligoarthra (e.g. Mac- 
rosetella gracilis) where naupliar postmaxillulary limb formation is absent (Dahms, 1990).

6) Six caudal setae at later metanauplii (Fig. 6): The caudal armature of non-copepod nauplii is difficult to ascertain, because spiniform processes found on some non-copepod nauplii may or may not have setal precursors. However, Cephalocarida, Branchiopoda, Mystacocarida, and Thecostraca have fewer than 6 caudal elements on each prospective caudal ramus. Six setae are widespread and this is the maximum number among all major copepod taxa. Six setae are present in the underived Oligoarthra-Maxillipedasphalea, but there is a lower number in some other harpacticoid taxa. Caudal setae are reduced in number and the number may be contralaterally asymmetrical in many Calanoida. Six caudal setae cannot be an apomorphy of Poecilostomatoida, as suggested by Izawa (1987), because this is shared character state of all late copepod metanauplii.

If these characters are accepted as common characters of non-polyarthran Copepoda, then the Polyarthra would become the sister-taxon of the remaining taxa of the Copepoda with which they share the followingfive synapomorphies (which are naupliar autapomorphies of the Copepoda as a whole as deduced from outgroup-comparison with other maxillopodan groups - $c f$. Dahms, 2004):

1) Two antennal coxal setae: In addition to the antennal enditic process of the coxa which is present throughout the naupliar phase (although rudimentary at NI), there is a peculiar strong seta at the base of this process developed at NIII stage in Calanoida and Cyclopoida (Dahms and Fernando, 1993). In some species of Oligoarthra a presumably homologous seta is present throughout the naupliar phase. Presence of this seta is a weak naupliar apomorphy for the Copepoda because its presence has not been wellstudied among all Maxillopoda.

2) 1-segmented antennal endopodite throughout the naupliar phase: see above (synapomorphies of Polyarthra and Copepoda).

3) Thoracopods 1 (=Mxp), 2 (=leg 1) and 3 (=leg 2) present at NVI stage: see above (synapomorphies of Polyarthra and Copepoda).
4) Postmandibular appendages juxtaposed medially in later metanauplii: In Cephalocarida, Branchiopoda und Mystacocarida there is a medial gap between contralateral pairs of metanaupliar postmandibular appendages. This character is not known from Thecostraca. Postmandibular appendages are juxtaposed medially in Cyclopoida, Polyarthra and Calanoida, whereas they are widely spaced secondarily in the Oligoarthra. This positional peculiarity indicates a striking difference between copepod cephalic and thoracic appendages.

5) Six caudal setae: see above (synapomorphies of Polyarthra and Copepoda). A sistergroup relationship of Polyarthra + remaining Copepoda provides a reasonable hypothesis, where the Polyarthra exhibit the most plesiomorphic character states. This is also indicated by nine plesiomorphic character states Polyarthra share with other groups of the Maxillopoda which lack, however, among all known nauplii belonging to non-polyarthran Copepoda. Although the author is aware of the fact that plesiomorphies do not provide direct evidence of relationships, they do restrict the number of states which than can express an apomorphy.

1) Antennule with 5 segments throughout the phase (Fig. 3): (6 segments for Longipedia minor - for NI still showing a 5-segmented state cf. Fig. 2) is unique insofar as there are no more than 3 segments in non-polyarthran Copepoda. Six antennular segments are characteristic for Cephalocarida (Sanders, 1963a) and lepadid Cirripedia (Grygier, 1987b), whereas a 5segmented antennule is common in other groups of Cirripedia (Izawa, 1987). There seems to be no functional necessity for the acquisition of additional segments of the antennule as an adaptation to pelagic performance (so secondary acquisition of segments to a presumed 3-segmented antennule would be expected to have no adaptive value). Swimming is performed successfully also by a 3-segmented antennule of calanoid nauplii. It is more likely that an antennule of more than 3 segments is a plesiomorphic character state, retained from maxillopodan ancestry. This view is supported by Grygier (1987b) who postulated that an 8-segmented antennule 
is a ground pattern state of nauplii belonging to the Maxillopoda.

2) The exopodal segments of the antenna of Polyarthra increase from 6 at NI to a final number of 9 at NIV (Fig. 5): An increase of segments is unknown from non-polyarthran Copepoda. Throughout the naupliar phase there are 6 segments in Cyclopoida and Calanoida and 9 in Mystacocarida and Cirripedia. InChthamalus stellatus (Cirripedia) there are 2 setae on the first seta-bearing segment, 1 seta on each of the following and 3 setae on the terminal segment (Egan, Anderson, 1989) as it is the case in the Polyarthra.

3) Multisegmented state of antennal endopodite (Fig. 5): The antennal endopodite is 2segmented in Cephalocarida and Facetotecta, 4segmented in Mystacocarida (or 3-segmented if the distal portion is interpreted as a complex seta), 3-segmented in Cirripedia (this may often appear 1-segmented in Cirripedia, due to fusion of segment 1 to the basis and segments 2 and 3 to each other partially - (M. Grygier, pers. comm.), and 3-segmented in Ascothoracida. As for the Copepoda, the only exception with a 2segmented endopodite is the taxon Cyclopoida. In the polyarthran Longipedia minor, there are spinule rows which may indicate the position of an arthrodial membrane of a former 2-segmented [or even a 4-segmented state at later developmental stages] of the antennal endopodite.

4) Lack of maxilla: The maxilla does not become visible externally nor are there traces discernible internally in the Polyarthra. This contradicts all studies of the nauplii of the Polyarthra to date which find the presence of a maxilla. This may be due to a misinterpretation of outer parts of the medial maxilliped anlage. If the maxilla does not develop externally in the nauplius, this would be a secondary loss the Polyarthra have in common with the Thecostraca (Cirripedia, Facetotecta and Ascothoracida). Among non-polyarthran Copepoda (except in some parasitic forms and some Oligoarthra where it is lacking) the maxilla appears at NIV or NV stage.

5) Swimming performance and life history: Polyarthran nauplii swim in a slow, jerky man- ner, performing circles while swimming on their backs as most nauplii of the Cirripedia do. This, besides other characters made Gurney (1930) and Nicholls (1935) emphasize the "resemblance"of the nauplii of Longipedia and the Cirripedia. Lauterbach (1980) argued that the creeping behaviour of nauplii is a plesiomorphic character within Harpacticoida and used this as a model to claim that the ancestral Crustacean larva (i.e. the nauplius) was also substrate-dwelling and non-planktic. Consequently, swimming ability and multi-segmented exopodites of the second antennae and mandibles must have developed secondarily (reversing the usually proposed reduction sequence). This is incompatible not only with the proposed maxillopodan ancestry of the Copepoda and the finding that Oligoarthra and the Polyarthra as a rule develop through nauplii that are excellent swimmers.

Nicholls (1935) admitted that at least the particular jerky swimming motion may be only a mechanical effect and attributed this to the long posterior spine present in both groups the Polyarthra and the Cirripedia. It has to be emphasized that a caudal process is of importance in swimming, probably as a balancing organ. This may explain its widespread occurrence among underived Crustacean taxa with planktic nauplii (except the benthic Mystacocarida). Among holoplanktic calanoid nauplii there are many cases where one of the two closely set longer caudal setae and its rami are reduced in size whereas the other is enlarged (Faber, 1966; Koga, 1984; Björnberg, 1986), thus, probably achieving the functional effect of only one long caudal seta. In this context, NI of the oligoarthranEuterpina acutifrons (a planktic species of Tachidiidae) is remarkable. It does not bear a caudal spine but rather the prominent, arched ventral portion of the abdomen is furnished with a semilunar-shaped row of long spinules, which may function in the same way as do the caudal setae at NI and the maxillule from NII onwards in Polyarthra.

As for the life history of Oligoarthra and Polyarthra, Dahms \& Qian $(2003,2004)$ speculate that because these larvae share the same realm as the adults and no costly habitat transi- 
tion is necessary. This contradicts conventional wisdom that there is an adaptive advantage for species in which larvae and juveniles or adults do not share the same habitat. Furthermore, Dahms (2000) observed that Leptastacidae develop nauplii and copepodids which are interstitial dwellers of marine coastal sands. Even if planktonic, both phases may share the same habitat:e.g.,Macrosetella gracilis (Miracidae) clasping cyanobacterial Trichodesmium filaments; nauplii and copepodids ofDrescheriella glacialis living in the interstices of Antarctic pack ice. The only exception is the Polyarthra. In both taxa, Longipediidae and Canuellidae (cf. Dahms, 2000, fig. 7), copepodids are always close to the substratum, it may be sediment or invertebrate host. The nauplii, however, are planktonic suspension feeders with good swimming abilities. This holds for free-living Canuellidae (Dahms, 1990) as well as for symbiotic taxa where nauplii have not been found at/in the host and, therefore, are suspected to constitute the planktonic infecting and dispersal phase ( $c f$. Huys, 1995). According to Huys (1995) Canuellidae inhabit a wide range of sediments from flocculent muds to coralline debris, and they are primarily found in the intertidal and shallow subtidal areas of the continental shelves. Some genera such as Canuella and Canuellopsis have been reported from deeper muds. Interpreting these as exceptions, the family has been unsuccessful in invading the deep sea realm. The absence of suspended food items in deeper waters suitable for nauplii of the Polyarthra might be the main ecological reason for both polyarthran taxa, being restricted with few exceptions to shallow waters (see Huys, 1995).

A swimming naupliar locomotion seems to be the underived state for the Crustacea. Functional reconstructions revealed that, as in feeding nauplii of extant Crustacea, the nauplius of Rehbachiella kinnekullensis (Branchiopoda) may have fed while swimming. Since this can be applied also to the maxillopodan larva ofBredocaris admirabilis(Müller, Walossek, 1988), the speculations of Lauterbach (1980) concering a creeping ancestral larval type for Crustacea must be rejected ( $c f$. Dahms, 1990).
6) $4^{\text {th }}$ pair of appendages (fig. 1): A much disputed and important question concerns the presence at NI stage of the Polyarthra of the anlage of the maxillule. Gurney (1930) described the NI of Longipedia (Longipedia, genus II) with 2 long spinulose setae posterior to the mandibles which he interpreted as the maxillules. This interpretation implied that no furcal setae are present. Lang (1948) also described the more caudal setae of NI of Sunaristes paguri as the maxillules and he declared the presence of the maxillule at NI as a constitutive character of the Polyarthra separating this taxon from the rest of Harpacticoida (and Copepoda as a whole). This interpretation has been followed by Nicholls (1935), Onbé (1984) and Izawa (1987). The presence of the maxillules at NI would be highly unexpected for the fact that this stage is supposed to be an orthonauplius in the Copepoda. The only authors interpreting the caudal setae of NI as belonging to the hind-body and not as the maxillule are Vincx \& Heip (1979), although they provided no explanation.

Nevertheless, the similarity of the presence of 2 stout setae at NI and 2 pairs of stout setae at NII within Longipedia and Canuella (Figs. $1,2)$ is so remarkable that these cannot but be homologous and it is more than likely that a maxillule is developed not earlier than from NII onwards in Longipediidae as well. The erroneous interpretation confuses the caudal setae with the maxillules at NI among Polyarthra and of the planktonic representatives of Ectinosomatidae (Hirakawa, 1974; Diaz, Evans, 1983), and may be due to the fact that these setae are longer than the caudal setae of NII. In this respect they resemble the maxillules. However, the fact that the caudal setae are so short at NII can be viewed as a functional shift (of balancing and stability) provided by long setae from the caudal setae at NI to the maxillules at NII. This is demonstrated by the epibenthic species of the Ectinosomatidae, in which the morphology of both the caudal setae and the maxillules are different from that of the planktic representatives, but similar to that of all other representatives of Oligoarthra studied ( $c f$. Dahms, 1990). 
The presence of maxillules at NI of Polyarthra would be the first case for the suppression of an orthonauplius among the Copepoda, Cirripedia and Ascothoracida (cf. Izawa, 1987), and would result in the reduction of the number of metanaupliar stages to five. An early appearance of the maxillule at NI would be of phylogenetic importance because it has been regarded both historically and recently as a primitive state. Lang (1946) argued that the protaspis larva with 4 pairs of appendages of the trilobites is not already "a specialized larval stage", but a primitive one, and that the first nauplius stage of crustaceans is a protaspis stage which is arrested and delayed in its development. Garstang and Gurney (1938) among others attempted to derive crustaceans from trilobites and the crustacean nauplius from the protaspis larva of trilobites. They interpreted the nauplius as a specialized (or modified) protaspis. However, as pointed out by Fryer (1992), little is known about the supposedly five appendages (vide Garstang and Gurney, 1938) of the trilobite protaspis. Cisne (1974) observes there are only four appendages. Fortey and Morris (1978) described a larval stage of trilobites that precedes the protaspis (or anaprotaspis as the first protaspis is often called). They identified this larva as a crustacean nauplius. The fossils, however, show no appendages and therefore, little about naupliar affinities can be inferred (cf. Fryer, 1992). Maas et al. (2003) give arguments that the Crustacean (ortho-) nauplius, as a larva having exactly three limbbearing segments, cannot be derived from a larva with four limb-bearing segments as having just reduced the segment number.

7) Antennule segment homologues of Polyarthra and other Copepoda (Fig. 3): InLongipedia minor the antennule is 6-segmented at NI and 5-segmented from NII to NVI ( $c f$. Dahms, 1990). From NI to NII a new, unarmed segment develops which subsequently is reduced in size to a mere disc at NVI, at which stage it probably functions as a joint for the paddle-like distal segment. At NI the antennule bears 1 long, spinulose seta each anteriorly on distal outgrowths of the $2 \mathrm{nd}$, 3rd and 5 th segments. The proximal seta remains situated on the $2 \mathrm{nd} \mathrm{seg-}$ ment but the two distal setae are both situated on the then demarcated 3rd segment at NII ( $c f$. Ferrari and Benforado 1998). Here, the antennule of NI of L. minor shows a cylindrical distal segment at NI which becomes flattened during subsequent moults until it is paddle-like in the last naupliar stage. The armature is confined to the lateral and terminal edges. Judging from its reduced size and disc-like appearance, the subdistal segment (representing segments III-V) probably serves as a joint for the paddle-strokes of the terminal segment - similar to segment 2 of calanoid nauplii called the "Wirbel" by Oberg (1906). In Oligoarthra, the number of segments of the antennule never exceeds 3 , and all segments are cylindrical throughout the phase.

Judging from setal composition and development, the unarmed 1st segment of oligoarthran antennules is homologous to that of Polyarthra. Segment 2 with 3 setae is homologous to segments $2-4$ of polyarthran metanauplii which also together bear 3 setae. Segment 3 is equivalent to the 5 th of Polyarthra which also bears 3 elements at NI and also increases its armature throughout the naupliar phase. The segment number of the antennule can be 1-3 in the Oligoarthra ( $c f$. Dahms, 1990). For species in which it is 3 -segmented, the 1 st segment is always unarmed and the 2nd segment always bears 3 setae, of which the distalmost is by far the longest. Homologues of these 3 setae (I-III) are assumed in the Polyarthra based on their position. Therefore, the unarmed segment of the 1st nauplius of the Polyarthra and Oligoarthra should be homologous; segments 2 and 3 of $L$. minor correspond to segment 2 in the Oligoarthra, and the distal segments of L. minor are homologous to the 3 rd segments in the Oligoarthra.

An antennule of 5 segments in the nauplii of Polyarthra (6 segments at NI of Longipedia minor, cf. Dahms, 1990) is unusual; there are no more than 3 segments in the other taxa of the Copepoda. On the other hand, six antennular segments are characteristic throughout the naupliar phase for the Cephalocarida (Sanders, 1963b), lepadid Cirripedia and Ascothoracida (Grygier, 1987a). 
There is no functional neccessity as an adaptation to a pelagic life for the acquisition of additional antennular segments (i.e. a secondary addition of segments to a presumed 3-segmented antennule). Calanoid nauplii swim successfully with 3-segmented antennules which have a flattened distal antennular segment similar to that in polyarthran nauplii. However, due to functional improvements, this has probably evolved independently in the nauplii of the two groups. An antennule of more than three segments may be a plesiomorphic character retained from a maxillopodan ancestor. This inference is supported by Grygier (1987a), who postulates an 8-segmented antennule as a constitutive feature of the Maxillopoda.

In L. minor the 3 proximal setae are retained on the 1 st segment of the antennule of copepodid I while the 1 st segment of the nauplius either becomes reduced or is fused to the former 2 nd segment (cf. Fig. 3). The same holds for oligoarthran antennules: the naupliar 1st segment is lost and the 2 nd naupliar segment gives rise to the 1 st segment of the copepodid antennule. This becomes particularly evident when the 1 st segment of CI still bears 3 setae, as in the oligoarthran Ectinosoma melaniceps, Parathalestris clausi, Tigriopus brevicornis and Amonardia normani (Dahms, 1989).Heterolaophonte minu$t a$, also belonging to the Oligoarthra, shows this best because its proximal setae have different morphologies and can thus be traced individually. Seta I is minute at NVI and is lost at CI. Seta II with its peculiar spinulous ornamentation is retained in its subdistal position and the large seta III in the most distal position. Seta II becomes lost at CII. As in other species (e.g. Ectinosoma melaniceps), the largest and most distal seta (seta III) is retained in later copepodids. Reductions confined to the most proximal segment are also observed in Scutellidium hippolytes and Tisbe, where 2 of the 3 setae become reduced from CI to CII (unpublished observations). With the exception of Macrosetella gracilis, where a seta at the dorsodistal corner of $\mathrm{CI}$ and CII is replaced by a row of spinules at CIII, and with spinules lost at CIV, all the harpacticoids studied, retain the large seta III on the dorsodistal corner of the 1st segment and only the more proximal setae are lost.

The same phenomenon of setal loss occurs on the distal antennular segments. Often, 1 tiny seta on the terminal segment ventral to the aesthetasc is lost from CI to CII (e.g. Tegastes clausi) (Dahms, 1989). Even a second seta, proximal to the terminal setae/aesthetasc complex, disappears inThalestris longimana (Dahms 1989, 1990). The setae which become lost here are homologous to those of the naupliar distal antennular segment. This is supported by identical seta numbers in, for instance, Longipedia minor and Heterolaophonte minuta (14 setae/ aesthetasc at both, NVI and CI).

The loss of setae on the antennules of early copepodids is interpreted as evidence for a higher ancestral number of antennular segments within the Polyarthra and Oligoarthra and other taxa by Dahms (1989). Dahms has suggested that the presence of additional setae on the $1^{\text {st }}$ and most distal segments of the antennules of the copepodids is a palingenetic recapitulation (or „haeckelian“ in the sense of De Beer, 1940); i.e. they indicate that stem line taxa of the Harpacticoida must have had more than 1 seta on their proximal segments as a ground pattern and additional setae on the distal segment at CI at least. Gurney (1931) as well as others have interpreted the presence of more setae than usual on a segment as an indication of a fusion of segments, and Dahms (1989) suggested that stem line (juvenile/adult) Harpacticoida had antennules with more segments than crown group representatives. That the setae which are lost among copepodids are actually those homologous to naupliar setae, and not those added during copepodid development, has not been stated previously. Dahms (1989) showed that an increase of seta number and segments during copepodid development takes place only in the middle of the appendage, leaving the most proximal and distal segments and presumably naupliar homologues conservatively unchanged. This supports the notion that the naupliar setal number is retained proximally and distally in early copepodids at least in some of the species studied. 
8) Dorsocaudal process (Fig. 6): A caudal spine is probably of functional importance for the swimming behaviour as a balancing organ. This would explain why it is developed only in the Polyarthra and planktonic larvae of the Oligoarthra, and is widespread among supposedly underived Crustacean groups with planktonic nauplii. Among other Copepoda a caudal process is known also from some Poecilostomatoida.

A short dorsocaudal spine is further present in nauplii of Mystacocarida, Ascothoracida, Facetotecta, and could grow out to a long process in some Cirripedia. In view of its important functional role it is not unlikely to assume that a caudal process has evolved independently for more than once, even among the "Maxillopoda". The 1st stage nauplius of Euterpina acutifrons, a planktonic harpacticoid belonging to the Tachidiidae (Harpacticoida - Oligoarthra, $c f$. Dahms, 1990) does not bear a caudal spine but a replacement structure. This is a remarkably prominent and arched ventral portion of the abdomen, furnished with a semi-lunar-shaped row of long spinules, probably forming a counterweight for balancing purpose as the caudal setae at early and the maxillules at later stages of the Polyarthra. A caudal process is present in some Cyclopoida and Polyarthra, whereas there is no indication of such a median structure in any representative of the Calanoida (however, there is a functional replacement-complex in most calanoid taxa - see below).

The naupliar dorsocaudal process of the Poecilostomatoida is interpreted by Izawa (1987) as homologous to that of Cirripedia, Ascothoracida, Facetotecta, and Mystacocarida. Izawa (1987) states that the caudal process is a part of the general plan of naupliar development among Cyclopoida s. l., although an unpaired caudal process is present only in the taeniacanthiform group of the Poecilostomatoida. It has to be emphasized that the spine/total body length ratio in Longipedia minor, L. americana (cf. Onbé, 1984), L. brevispinosa (cf. Koga, 1984) and $L$. scotti ( $c f$. Nicholls, 1935) decreases from NI to NIV and is completely lost at NV and NVI in L. weberi (cf. Koga, 1984). In M. norvegica the cone-like caudal spine of NI is reduced in size at NII and completely lost at NIII (Koga, 1984). Its early appearance and later reduction probably indicates its plesiomorphic larval character state.

A dorsocaudal spine is probably of functional importance during swimming which may explain why it is developed only in planktonic larvae of the Harpacticoida, such as in all known species of Longipediidae (Polyarthra) and in Microsetella norvegica, a planktonic representative of Ectinosomatidae. Nauplii of Longipediidae are characterized by a dorsocaudal process and a similar structure is also present in later copepodids.

This spine, decreases in relative length during development. The furcal setae arise from a ventrodistal bulge and, with the caudal process, form a tri-partite unit probably functionally important for balancing. The furcal setae are very stout at NI. At NII they become drastically reduced in size and lose their spinular ornamentations. Then they bear long spinules on the outer edge of the distal third. The balancing function is probably taken over by the newly developed maxillules which are nearly as strong and spinulose as the caudal setae of NI. At NIII there are 3 , and at NIV and NV 4 caudal setae. At NVI, 6 setae are present (Fig. 6).

The spine/total body length ratio decreases in Longipedia minor (present study),L. americana (Onbé, 1984),L. brevispinosa (Koga, 1984) and L. scotti (Nicholls, 1935) throughout the phase, but it decreases from NI - NIV until it is completely lost at NV and NVI in L. weberi (Koga, 1984). In M. norvegica the cone-like caudal spine of NI is reduced in size at NII and is completely lost at NIII(Diaz, Evans, 1983; Koga, 1984). According to Hirakawa (1974) this spine is reduced already at NII and Björnberg (1972) does not mention it at all for $M$. rosea.

This spine is widespread in the nauplii of other Copepoda and „Maxillopoda“. In his description of the development of the parasitic Taeniacanthus lagocephali (Taeniacanthidae), Izawa (1986b) states that the two naupliar stages present in this species have short caudal spines. Izawa (1986a) describes a caudal process for the nauplii of 4 families of poecilostome 
cyclopoids: Anchistrotos pleuronichthydis (Taeniacanthidae), Tegobomolochus nasicola (Tegobomolochidae), Doridicola sepiae and Nasomolgus firmus (Lichomolgidae). Izawa (1987) considers the caudal process to be a part of the general plan of naupliar development among Cyclopoida although an unpaired caudal process is present only in certain species of this group.

Delamare-Debouteville (1954) described a shorter caudal spine from at least the first eight developmental instars of the benthicDerocheilocaris remanei (Mystacocarida $-c f$. also Olesen, 2001). The caudal process is also common in Ascothoracida (Grygier, 1987a), „Facetotecta“ (e.g. Itô, 1986a) and Cirripedia (e.g. Hansen, 1899). The same holds for fossil Crustacea ( $c f$. Walossek, 1993). Among other characters, it is the caudal process which makes Gurney (1930) and Nicholls (1935) stress the resemblance between the nauplii of Longipedia and that of cirripedes. The dorsocaudal spine is most likely an autapomorphy of Eucrustacea - and therefore a plesiomorphy in any in-group taxon (Waloszek, pers. comm.).

9) Evidence for larger numbers of segments in ancestral naupliar antennal endo- and exopodites: In Longipedia minor the naupliar antennal endopodite is 1-segmented and bears 2 transverse rows of spinules in addition to the setae on the inner edge; 1 row is found at midlength and the other more irregular one on the distal edge (Fig. $5-c f$. Dahms, 1991). The setae at midlength and its associated spinule row may indicate the location of armature and arthrodial membrane of the first of an ancestral 2 -segmented endopodite. Spinule rows often accompany segments which are separated by arthrodial membranes in many Copepoda and in the Polyarthra (see Figs. 5A, B). In the Oligoarthra only the seta(e) at midlength remain as observed in the primitivePhyllognathopus viguieri and the more derivedScutellidium hippolytes. A transverse spinule row has never been observed at midlength in nauplii of the Oligoarthra. At NVI of Longipedia minor there are 2 additional rows of spinules on the endopodite one proximal to the row at midlength and one distal to it. Assuming that these are the distal fringing ornamentation of formerly separate segments, 4 segments may have been present in the ancestral endopodite. However, a 4-segmented antennal endopodite is unknown from nauplii of extant Crustacea.

The exopodal segments of Polyarthra increase from 6 at NI to 7 at NII, 8 at NIII and the final number of 9 at NIV-VI (Dahms, 1990). In the Oligoarthra, there is no increase in segment number of the antennal exopodite except for Phyllognathopus viguieri (Phyllognathopodidae), where a new $2^{\text {nd }}$ segment is added at NIII to the 4-segmented exopodite of NII; at NVI the exopodite is indistinctly 5-6 segmented, because another unarmed disc-shaped segment develops distal to the outer margin of the $2^{\text {nd }}$ segment (Dahms, 1990). In other oligoarthran taxa the segment number is $1-5$ constantly throughout the naupliar phase. However, the setae on the proximal and distal segments which are formed in the course of naupliar development (e.g. those indicated by arrowheads in Scutellidium hippolytes) probably are indicative of a larger number of segments of this ramus. Apart from the 6 to 9 segments seen at various naupliar instars in L. minor, there are spinule rows on the $2^{\text {nd }}$ segment at NVI, suggesting former segment borderlines. The proximal spinule row of the $2^{\text {nd }}$ segment at NVI and its subdistal $2^{\text {nd }}$ seta, however, may indicate 2 further segments, thus providing a segment number of 11. Additionally, it can be argued that the 3 setae on the terminal segment indicate another 2 segments (if one seta per segment is the rule for the underived state, $c f$. Gurney, 1931; VaupelKlein, 1984), giving rise to an ancestral number of 13 segments for the naupliar antennal exopodite of L. minor. It seems more reasonable to assume, however, that a crown group of 3 setae represents the groundpattern in the Copepoda, leaving a number of 11 segments for the naupliar antennal exopodite as the ground-pattern of the Polyarthra.

The antennal exopodite is 13-segmented in Cephalocarida, 9-segmented in Mystacocarida and Cirripedia, 8-segmented in most Ascothoracida. However, there are up to 13 segments in planktotrophic, late metanaupliar ascothora- 
cidans ( $c f$. Boxshall, Böttger-Schnack, 1988). Most nauplii of the Facetotecta are described as having 4-5-segmented antennal exopodites. According to Itô (1990) they are 6-segmented. Among copepod nauplii 6-segmented exopodites are widespread, and copepod nauplii do not show a higher segment number (with the exception of later stages of Polyarthra and certain Cyclopoida belonging to Oncaeidae and Corycaeidae, the latter with 7 segments at later naupliar stages; $c f$. Koga, 1984). However, in some species the 6-segmented state is acquired only at later stages (at NIII in some representatives of Cyclopoida; $c f$. Dahms, Fernando, 1993). Reduction of segment number takes place independently especially in parasitic taxa of the Cyclopoida and Harpacticoida (Dahms, 1992).

The increase in segment number of the antennal exopodite in the Polyarthra (from 6 segments at NI to 9 at NIV) is unknown in other groups of Copepoda or Maxillopoda. In the Cyclopoida and Calanoida there are 6 segments among all nauplii, whereas there are 9 in the Mystacocarida and Cirripedia. In Chthamalus stellatus (Cirripedia), for instance, there are 2 setae on the 1st seta-bearing segment, 1 seta on each of the following segments, and 3 setae on the terminal segment (Bassindale, 1936), as is the case in the Polyarthra. However, there might be an increase of segments during the naupliar development of some Cirripedia as this has been reported for Ascothoracida (Itô, Grygier, 1990). Although neither a reconstructed 13-segmented nor an observed 9-segmented naupliar antennal exopodite is known from any other copepod taxon, a 12-segmented antennal exopodite was shown for an ascothoracid metanauplius type I by Boxshall and Böttger-Schnack (1988).

No indication of a 2 nd segment on the endopodite of the second antenna has been reported from any other copepod group except the Cyclopoida (e.g. Gurney, 1932), where the endopodites are 2-segmented. But 2 and even 3 segments are common for other taxa of the Maxillopoda and the Cephalocarida. Ascothoracida (Grygier, 1987a), Facetoteca (Itô, 1986b) and Cephalocarida (Sanders, 1963b) bear a 2-segmented endopodite throughout the phase, whereas Mys- tacocarida (Olesen, 2001) bear a 3-segmented one. Boxshall and Böttger-Schnack (1988) described a 3-segmented antennal endopodite also from a late metanauplius of the Ascothoracida. In Cirripedia a formerly 3 -segmented endopodite might be present (Grygier, pers. comm.). A 2segmented condition may be indicated by an indentation of the inner middle portion which bears a bundle of setae. In nauplii of the cirriped Chthamalus stellatus (Bassindale, 1936) there are 4 medial setae, as there are in later stages of both taxa belonging to the Polyarthra (Dahms, 1990).

\section{Phylogenetic affinities within the Maxillopoda}

Dahl (1956) included the Ascothoracida, Branchiura, Cirripedia, Copepoda and Mystacocarida into the taxon Maxillopoda. Later, the Ostracoda, Facetotecta, and Pentastomida were included as extant taxa, as well as the fossil species Bredocaris (Orstenocarida) and Skara (Skaracarida) (Walossek, 1993). On the other hand Abele et al. (1992) do not allocate the Branchiura and Mystacocarida to the Maxillopoda.

Branchiura, Tantulocarida and Pentastomida appear to lack naupliar stages, and data on ostracod nauplii are limited so that not all maxillopodan taxa considered in the present study. Because the Maxillopoda show several features in reduced states ( $c f$. Dahl, 1956), there is a question concerning the process effecting these features. Progenetic paedomorphosis is one process which explains these features. Since the ancestral condition among the Crustacea in general comprises anamorphic development, it was inferred that a reduction in the number of larval instars was achieved by progenetic paedomorphosis, precocious maturity of a larval form. However, paedomorphosis may merely be an convenient mechanism to explain a reduction in number of somites or appendages, when a biramous mandibular palp is retained in the adult.

The Maxillopoda usually have feeding nauplii. The retention of the larval feeding mechanism in the adult stage is believed to be the first 
step in the evolution of all maxillopodan groups. It represents a prerequisite for the specialization of the thorax as a locomotory center and the head as a center for feeding. Sanders (1963a) postulated that the metanauplii of cephalocarids and mystacocarids are the most plesiomorphic among Crustacea in their retention of a primitively benthic mode of life and correlated morphological features. If this is true, one cannot specify apomorphic states unique to maxillopodan nauplii. Rather, most of their common features would seem to be plesiomorphic for Crustacea in general.

The Thecostraca Gruvel (1905) (comprising the Cirripedia, Ascothoracida, Facetoteca (cf. Grygier, 1987a)) have three naupliar characters in common which are unique among crustacean nauplii and provide strong autapomorphies characterizing this monophyletic taxon ( $c f$. Dahms, 2004): absence of appendages caudal to the maxillule; presence of frontal filaments; presence of lateral ridges [where are the lateral ridges]. Dahms (2004) hypothesized a sister-group relationship of the Copepoda and the Thecostraca. This hypothesis can be extended to a sister-group relationship between the Polyarthra as an underived branch of the Copepoda and the Thecostraca based on the following three synapomorphies (for a phylogenetic diagram $c f$. Dahms, 2004): six naupliar stages; absence of somite borders throughout the naupliar phase; pronounced changes between nauplius and subseqient phase.

\section{Discussion}

Grygier (1983) stated that naupliar characters can be dismissed for the characterization of the Maxillopoda as a monophylum because they either are plesiomorphic or represent convergences. Here naupliar characters are inspected and successfully used as synapomorphies for the subtaxa Thecostraca and Copepoda. The phylogenetic relationships within the Thecostraca and the monophyletic status of the Thecostraca + Copepoda was previously suggested by Schram (1986: 538, fig. 43.6), who based his conclusions mainly on adult characters. His cladogram includes an unresolved trichotomy, with the Tantulocarida as one branch, the Copepoda and its sister-taxon Thecostraca as the second, and the Branchiura, Mystacocarida plus Ostracoda as the third branch. The approach of Grygier (1987a), using mainly naupliar and cyprid characters, united the Cirripedia, Ascothoracida and Facetotecta as the monophylum Thecostraca. He suggested that the Branchiura is the sister-group of the Thecostraca, and that the Copepoda, exhibiting the most plesiomorphic character states, is the sister-group of Branchiura plus Thecostraca. Grygier (1987a) could not provide any apomorphy for all five taxa together. Boxshall and Huys (1989) also suggested two main lineages within the Maxillopoda, one leading to the Copepoda core (comprising Copepoda, Mystacocarida, Skaracarida) and the other to the Thecostraca core (comprising Thecostraca, Branchiura, Ostracoda) ( $c f$. Dahms, 2004).

Regarding adult characters, the Polyarthra fit into the character scenario already depicted for the ancestral copepod by Boxshall et al. (1986). This, however, is largely a result of the underlying assumption that copepod evolution has proceeded by oligomerization ( $c f$. Hessler, Newman, 1975 - for the Crustacea in general). Also, the naupliar synapomorphies Polyarthra share with all other Copepoda (see above) leave no doubt about their affinity to the Copepoda. Both character sets, however, from naupliar as well as from juvenile and adult semaphoronts, provide evidence for the exclusion of the Polyarthra from the Harpacticoida. Polyarthra do not share a single naupliar synapomorphy with Oligoarthra. As for adult characters, Thiemann (1984) critically evaluated the diagnostic characters provided by Lang (1948) for the Harpacticoida and concluded that no convincing apomorphies for the Harpacticoida are recognizable. Even a short antennule is plesiomorphic in the light of maxillopodan ancestry, providing a plesiomorphic character in probably reduced state. According to Thiemann (1984), the whole question about the phylogenetic allocation of the Podoplea center on the antennular segment number, but the derived states cannot be deter- 
mined because the original segment number is not discernable. Thiemann (1984) suggested that in order to reduce the number of plesiomorphic diagnostic characters of the Polyarthra, the Polyarthra be placed as an underived taxon at the base of the Copepoda, close to stem-line representatives of the podoplean Cyclopoida. There is no need, however, to establish a new taxon name for non-polyarthran Harpacticoida for the fact that the Oligoarthra are then the only taxon left from the Harpacticoida sensu Lang (1948). To summarize, Thiemann (1984) based his argumentation solely on the adult organization, did not provide sufficient reproducible character information, yet came to the same phylogenetic conclusion as the present study which used non-overlapping naupliar characters as a data source for phylogenetic inferences.

According to Huys and Boxshall (1991), on the other hand, there is no reason as far as adult characters are concerned, to exclude the Polyarthra from the Harpacticoida. They hypothesize the following apomorphies for the Harpacticoida sensu Lang (1948): Fusion of particular segments on the female and male antennule, presence of only 3 setae on the inner margin of exopodal segment 3 of second swimming leg, presence of only 1 seta on the inner margin of endopodal segment 2 of first swimming leg, a 2-segmented maxillipedal endopodite in which the ancestral segment 5 is incorporated into the compound proximal segment, retention of relatively plesiomorphic states of derived characters given for the Poecilostomatoida-Siphonostomatoida-Monstrilloidaclade. None of these character states provides a unique apomorphy. Furthermore, all of these characters are meristic and in reduced state. As for the maxilliped of the Oligoarthra, the distal part of the claw (=subchela) is a 2-segmented endopodite; a very careful analysis of the addition of setae suggests that the endopodite of Polyarthra is either 4-segmented (in the Longipediidae) or 3-segmented (in the Canuellidae) (seeFerrari,Dahms, 1998). Therefore, the polyarthran endopodite does not bear the 6-segmented ramus suggested by Huys and Boxshall (1991).

Ho (1990) did not analyse the Harpacticoida in particular but allocated them as a more de- rived clade of the Copepoda together with the Gelyelloida and the Mormonilloida. A similar allocation results from the analysis of Huys and Boxshall (1991) where the Harpacticoida (Polyarthra plus Oligoarthra) are the sister taxon of the Poecilostomatoida-SiphonostomatoidaMonstrilloida-clade, which is relatively derived compared to the Platycopioida, Calanoida and Mormonilloida.

Are Polyarthra and Oligoarthra sister taxa or a paraphyletic assemblage? Here we have a case of conflicting evidence caused by characters derived from two phases of ontogenetic semaphoronts. If the interpretation of adult characters is correct, one may ask how naupliar characters fit into this scheme. There are two possibilities of character interpretation:

a) Naupliar characters are conservatively unchanged: It is possible that both phases of Polyarthra, the naupliar and the copepodid phases leading to the adults, have evolved with different degrees of evolutionary radiation. Nauplii, therefore, may be conservatively unchanged, whereas the juvenile/adult forms have evolved to their present derived state.

b) Plesiomorphic naupliar characters are reaquired: Evolutionary progress in general and for Crustacea in particular may be characterized by specialization, often accompanied by reductions and simplifications leading from a homonomous and polymeric organization to a heteronomous and oligomeric state of somites and appendages. This is the concept of oligomerization which was probably elaborated best by Dogiel (1954), who understood oligomerisation as the evolution and specialization of various groups of metazoa accompanied by gradual reduction of a number of homologous organs. This oligomerization of a number of organs evolved to different systems of organs and is observed through quite different specializations. However, the reverse could also be true. Why should a secondary annulation and increase in segments, setae, etc. not have occurred? Secondly, Dollo's law (saying basically that structures that had been lost in evolution can never be reacquired exactly in the same form) has been invalidated by genetic analysis, for instance in 
fruit flies. These show that changes in the timing of gene repression or alteration of repressor molecules can restore ancestral gene function (cf. Ferrari, 1988). The reappearance of ancestral characters, reversals, or, "taxic atavism" (Stiassny, 1992) represents a major problem for phylogenetic reconstructions. When apomorphic character states of a taxon do not differ from corresponding plesiomorphic character states, then character polarity becomes obscured.

\section{Acknowledgements}

I am indebted to Professor Dr. H.K. Schminke for his unfailing interest in my work, his valuable suggestions, constructive criticism, encouragement and counsel. He also provided laboratory facilities and access to his collection of developmental instars. This evaluation would also not be tenable without the numerous contributions on naupliar development by other researchers; to name only: Tagea Björnberg (Sao Paulo), GeoffBoxshall(London), Frank Ferrari (Washington D.C.), Geoffrey Fryer (Ambleside), Mark Grygier (Lake Biwa), Jens Thorwald Hřeg (Kopenhagen), Tatsunori Itô (Kyoto), Kunihiko Izawa (Mie), Andreas Maas (Ulm) and Dieter Walossek (Ulm). The author, however, is fully responsible for the contents of this contribution. I am grateful to M. Bergmans (Brussels), R.Böttger-Schnack (Kiel), L. Brendonck (Brussels), S. Chullasorn (Bangkok), G. Dieckmann(Bremerhaven), R. Elofsson(Lund), F. Evans (North Shields), R.R. Hessler (La Jolla), N.M. Korovchinski (Moscow), P. Martinez-Arbizu (Oldenburg), M. Rieper, D. Schwentzer (Helgoland) and M. Spindler (Kiel) for providing me with the postembryonic stages of various crustaceans. Special thanks are due to M. Rieper, K. Anger, the late Günther Tadday and to the staff of the Biologische Anstalt Helgoland (Meeresstation Helgoland) for providing me with material and laboratory facilities. The „Alfred-Wegener-Institut für Polar- und Meeresforschung" (Bremerhaven) offered me to participate in the Ant V/3, Ant VII/4 and Ant $\mathrm{XIII} / 3$ expeditions of RV Polarstern to the Weddell Sea (Antarctica). Finally, I wish to thank the technical staff of the department for assistance and my colleagues for encouragement. Mrs. Julia Delingat, Sophie Martyna, and Conny Pfeiffer assisted in the preparation of figures and text. This study was funded by the DFG - HUD being the principal investigator (Da256/7-1; Da 256/10-1) and DAAD (436 RUS 17/20/98; A/99/09723).

\section{Literature}

Abele L.G., Spears T., Kim W., Applegate M. 1992. Phylogeny of selected maxillopodan and other crustacean taxa based on $18 \mathrm{~S}$ ribosomal nucleotide sequences: A preliminary analysis // Acta Zoologica. Vol.73 No.5. P.373-382.

Anderson D.T. 1994. Barnacles. Structure, function, development and evolution. London: Chapman and Hall. $357 \mathrm{p}$.

Ax P. 1987. Systematik in der Biologie. Stuttgart: UTB, G. Fischer Verlag. $181 \mathrm{~S}$.

Bassindale R. 1936. The developmental stages of three English barnacles, Balanus balanoides (Linn.), Chthamalus stellatus (Poli), and Verruca stroemia (O. F. Müller) // Proc. Zool. Soc. London. Vol.106. P.57-64.

Björnberg T.K. S. 1972. Developmental stages of some tropical and subtropical planktonic marine copepods // Uitgaven Naturweet Studiekring Suriname ned. Antillen. Vol.69. P.1-185.

Björnberg T.K.S. 1986. The rejected nauplius: A commentary // Syllogeus. Vol.58. P.232-236.

Boxshall G.A., Böttger-Schnack R. 1988. Unusual ascothoracid nauplii from the Red Sea // Bull. Brit. Mus. Nat. Hist. Vol.54. No.6. P.275-283.

Boxshall G.A., Huys R. 1989. New tantulocarid Stygotantulus stocki, parasitic on harpacticoid copepods, with an analysis of the phylogenetic relationships within the Maxillopoda // J. Crust. Biol. Vol.9. P.126-140.

Boxshall G.A., Ferrari F. D., Tiemann H. 1986. Studies on Copepoda II. The ancestral copepod: towards a consensus of opinion at the first international conference on Copepoda // Crustaceana Suppl. Vol.7. P.68-84.

Cisne J. L. 1974. Trilobites and the origin of arthropods // Science Vol.186. P.13-18.

Dahl E. 1956. Some crustacean relationships // K.G. Wingstrand (ed.). Bertil Hanström, Zoological papers in honour of his sixtyfifth birthday, November 20, 1956. Zoological Institute, Lund: Zoological Institute, Sweden. P.138-147.

Dahms H.-U. 1989. Antennule development during copepodite phase of some representatives of Harpacticoida (Copepoda, Crustacea) // Bijdr. tot Dierk. Vol.59 H.3. P.159-189.

Dahms H.-U. 1990. Naupliar development of Harpacticoida (Crustacea, Copepoda) and its significance for phylogenetic systematics// Microfauna Marina. Vol.6. P.169-272. 
Dahms H.-U. 1991. Usefulness of postembryonic characters for phylogenetic reconstruction in Harpacticoida (Crustacea, Copepoda) // Bull. Plankton Soc. Japan, Spec. P.87-104.

Dahms H.-U. 1992. Metamorphosis between naupliar and copepodid phases in the Harpacticoida // Phil. Trans. R. Soc. Lond. Vol.B 335. P.221-236.

Dahms H.-U. 2000. Phylogenetic implications of the Crustacean nauplius. Advances in copepod taxonomy // Hydrobiologia. Vol.417. P.91-99.

Dahms H.-U. 2004. Postembryonic apomorphies proving the monophyletic status of the Copepoda //Zoological Studies. Vol.43. No.2 (in press).

Dahms H.-U., Fernando C.H. 1993. Redescription of Mesocyclops leuckarti (Copepoda, Cyclopoida), including a study of its naupliar development // Int. Revue ges. Hydrobiol. Vol.78. P.589-609.

Dahms H.-U., Qian P.Y. 2004. Life histories of the Harpacticoida (Copepoda, Crustacea) - a comparison with meiofauna and macrofauna // J. Nat. Hist. (in press)

De Beer G.R. 1940. Embryos and Ancestors // Oxford Universitiy Press.

Delamare-Debouteville C. 1954. III. Le developpement postembryonnaire des Mystacocarides // Arch. Zool. Exp. Gen. (Paris). Vol.91. No.1. P.25-34.

Diaz W., Evans F. 1983. The reproduction and development of Microsetella norvegica (Boeck)(Copepoda, Harpacticoida) in Northumberland coastal waters // Crustaceana. Vol.45. No.2. P.113-130.

Dogiel V.A. 1954. [Oligomerization of the homologous organs as one of the main ways of evolution of animals]. Leningrad: Leningrad University Press. 368 p. [in Russian]

Dudley P. L. 1966. Development and systematics of some Pacific marine symbiotic copepods. A study of the biology of the Notodelphyidae, associates of ascidians // Univ. Wash. Publs. Biol. Vol.21. P.1-282.

Egan E.A., Anderson D.T. 1989. Larval development of the chthamaloid barnacles Catomerus polymerus Darwin, Chamaesipho tasmanica Foster \& Anderson and Chthamalus antennatus Darwin (Crustacea: Cirripedia) // Zool. J. Linn. Soc. Vol.95. P.1-28.

Faber DJ. 1966. Free-swimming copepod nauplii of Narragansett Bay with a key to their identification // J. Fish. Res. Bd. Canada. Vol.23. P.189-205.

Ferrari F.D. 1985. Postnaupliar development of a lookingglass copepod, Pleuromamma xiphias (Giesbrecht, 1889), with analyses of distributions of sex and asymmetry // Smithsonian Contributions to Zoology. No.420. P.1-55.

Ferrari F.D. 1988. Evolutionary transformations and Dollo's law // J. Crust. Biol. Vol.8. P.618-619.

Ferrari F.D. 1995. Six copepodid stages of Ridgewayia klausruetzleri, a new species of calanoid copepod (Ridgewayiidae) from the barrier reef in Belize, with comments on appendage development // Proc. Biol. Soc. Washington. Vol.108. P.180-200.

Ferrari F.D., Benforado A. 1998. Setation and setal groups on antenna 1 of Ridgewayia klausruetzleri, Pleuro- mamma xiphias, and Pseudocalanus elongatus (Crustacea: Copepoda: Calanoida) during the copepodid phase of their development // Proc. Biol.Soc. Washington. Vol.111. P.209-221.

Ferrari F.D., Dahms H.-U. 1998. Segmental homologies of the maxilliped of some copepods as inferred by comparing setal numbers during copepodid development // J. Crust. Biol. Vol.18. No.2. P.298-307.

Ferrari, F.D., Ivanenko V.N. 2001. Interpreting segment homologies of the maxilliped of cyclopoid copepods by comparing stage-specific additions of setae during development // Organisms, Diversity and Evolution Vol.1. No.2. P.113-131.

Ferrari, F.D., Markhaseva E. 1996. Parkius karenwishnerae, a new genus and species of calanoid copepod (Parkiidae, new family) from benthopelagic waters of the eastern tropical Pacific Ocean // Proc. Biol. Soc. Washington. Vol.109. P.264-285.

Ferrari, F.D., Steinberg D. 1993. Scopalatum vorax (Esterly, 1911) and Scolecithricella lobophora Park, 1970 calanoid copepods (Scolecitrichidae) associated with a pelagic tunicate in Monterey Bay // Proc. Biol. Soc. Washington. Vol.106. P.467-489.

Fortey R.A., Morris S.F. 1978. Discovery of nauplius-like trilobite larvae// Palaeontology. Vol.21. No.4. P.823833.

Fryer G. 1992. The origin of the Crustacea // Acta Zoologica Vol.73. No.5. P.273-286.

Garstang W., Gurney R. 1938. The descent of Crustacea from Trilobites and their larval relations //Evolution essays presented. Oxford. P.271-286.

Grygier M.J. 1983. Ascothoracida and the unity of Maxillopoda // F.R. Schram (ed.). Crustacean Phylogeny. Rotterdam: Balkema. P.73-104.

Grygier M. J. 1987a. Nauplii, antennular ontogeny, and the position of the Ascothoracida within the Maxillopoda // J. Crust. Biol. Vol.7. No.1. P.87-104.

Grygier M.J. 1987b. New records, external and internal anatomy, and systematic position of Hansen's y-larvae (Crustacea: Maxillopoda: Facetotecta) // Sarsia. Vol.72. P.261-278.

Gurney R. 1930. The larval stages of the copepod Longipedia // Jour. Mar. Biol. Assoc. Vol.16. No.2. P.461474.

Gurney R. 1931. British fresh-water Copepoda. Vol.1. General part and Calanoida. London: Ray Society. $238 \mathrm{p}$.

Gurney R. 1932. British fresh-water Copepoda. II. Harpacticoida. London: Ray Society. 336 p.

Gurney R. 1942. Larvae of decapod Crustacea. Weinheim: H.R. Engelmann. 306 p.

Hansen H.J. 1899. Die Cladoceren und Cirripeden der Plankton-Expedition // Ergeb. d. Plankton-Exped. d. Humboldt Stiftung. Bd. 2.

Hessler R.R., Newman W.A. 1975. A trilobitomorph origin for Crustacea // Fossils Strata. Vol.4. P.437-459.

Hirakawa K. 1974. Biology of a pelagic harpacticoid copepod, Microsetella norvegica (Boeck) in Oshoro Bay, Hokkaido // Bull. Plankton Soc. Jap. Vol.21. No.1. P.41-51. 
Ho J.-S. 1990. Phylogenetic analysis of copepod orders // J. Crust. Biol. Vol.10. No.3. P.528-536.

Huys R. 1995. A new genus of Canuellidae (Copepoda, Harpacticoida) associated with Atlantic bathyal seaurchins // Zoologica Scripta. Vol.24. No.3. P.225-243.

Huys R., Boxshall G.A. 1991. Copepod evolution. The Ray Society. 468 p.

Itô T. 1986a. A new species of "Cypris Y" (Crustacea: Maxillopoda) from the North Pacific // Publ. Seto Mar. Biol. Lab. Vol.31. No.3/6. P.333-339.

Itô T. 1986b. Three types of "Nauplius Y" (Maxillopoda: Facetotecta) from the North Pacific // Publ. Seto Mar. Biol. Lab. Vol.31. No.1/2. P.63-73.

Itô T. 1990. Naupliar development of Hansenocaris furcifera Itô (Crustacea: Maxillopoda: Facetotecta) from Tanabe Bay // Japan. Publ. Seto Mar. Biol. Lab. Vol.34. No.4/6. P.201-224.

Itô T., Grygier M.J. 1990. Description and complete larval development of a new species of Baccalaureus (Crustacea: Ascothoracida) parasitic on a zoanthid from Tanabe Bay, Honshu, Japan //Zool. Sci. Vol.9. P.485515.

Izawa K. 1986a. On the development of parasitic Copepoda. IV. Ten species of poecilostome cyclopoids, belonging to Taeniacanthidae, Tegobomolochidae, Lichomolgidae, Philoblennidae, Myicolidae, and Chondracanthidae //Publ. Seto Mar. Biol. Lab. Vol.31. No.3/6. P.81-162.

Izawa K. 1986b. On the development of parasitic Copepoda. III. Taeniacanthus lagocephali Pearse (Cyclopoida: Taeniacanthidae)// Publ. Seto Mar. Biol. Lab. Vol.31. No.1/2. P.37-54.

Izawa K. 1987. Studies on the phylogenetic implications of ontogenetic features in the poecilostome nauplii (Copepoda: Cyclopoida) // Publ. Seto Mar. Biol. Lab. Vol.32. No.4/6. P.151-217.

Jägersten G. 1972. Evolution of the metazoan life cycle. London, New York: Academic Press. 282 p.

Kesling R.V. 1951. The morphology of ostracod molt stages // Ill. Biol. Monogr. No.21. P.1-126.

Koga F. 1984. Morphology, ecology, classification and specialization of copepod nauplius // Bull. Nansei Reg. Fish. Res. Lab. Vol.16. P.95-229.

Lang K. 1946. A contribution to the question of the mouthparts of the Copepoda // Ark. Zool. A38 (5). P.1-24.

Lang K. 1948. Monographie der Harpacticiden I und II. Koenigstein, W-Germany: Otto Koeltz Science Publ. $1682 \mathrm{~S}$.

Lauterbach K.-E. 1980. Schlüsselereignisse in der Evolution des Grundplans der Arachnata (Arthropoda) // Abh. naturw. Ver. Hamburg (N.F.). Bd.23. S.163327.

Maas A., Waloszek D., Müller K.J. 2003. Morphology, Ontogeny and phylogeny of Phosphatocopina (Crustacea) from the Upper Cambrian "Orsten" of Sweden // Fossils and Strata. Vol.49. P.1-238.

Müller K.J., Walossek D. 1988. External morphology and larval development of the Upper Cambrian maxillo- pod Bredocaris admirabilis // Fossils and Strata. Vol.23. P.1-70.

Nicholls A.G. 1935. The larval stages of Longipedia coronata Claus, L. scotti G. O. Sars and L. minor T. \& A. Scott, with a description of the male of $L$. scotti // J. mar. biol. Assoc. U. K. Vol.20. No.1. P.29-45.

Oberg M. 1906. Die Metamorphose der Plankton-Copepoden der Kieler Bucht // Wissensch. Meeresunters., Abt. Kiel N.F. Bd.9. S.39-103.

Olesen J. 1999. Larval and post-larval development of the branchiopod clam shrimp Cyclestheria hislopi (Baird, 1859) (Crustacea, Branchiopoda, Conchostraca, Spinicaudata) // Acta Zoologica. Vol.80. P.163-184.

Olesen J. 2001. External morphology and larval development of Derocheilocaris remanei Delamare-Deboutteville \& Chappuis, 1951 (Crustacea, Mystacocarida), with a comparison of crustacean segmentation and tagmosis patterns. Kongelige Danske Videnskabernes Selskab. Biologiske Skrifter. 53. P.1-59.

Onbé T. 1984. The developmental stages of Longipedia americana (Copepoda: Harpacticoida) reared in the laboratory // J. Crust. Biol. Vol.4. No.4. P.615-631.

Rice A.L. 1986. Zoeal evidence for brachyuran phylogeny // F.R. Schram (ed.). Crustacea, 14. N.Y.: Oxford Univ. Press. P.313-347.

Sanders H.L. 1963a. The Cephalocarida, functional morphology, larval development, comparative external anatomy // Mem. Conn. Acad. Arts Sci. 15. P.1-80.

Sanders H.L. 1963b. XIII. Significance of the Cephalocarida // H.B. Whittington, W.D.J. Rolfe (eds.). Phylogeny and Evolution of Crustacea. Spec. Publ. Mus. Comp. Zool., Cambridge, Massachusetts. P.163-175.

Schram F.R. 1986. Crustacea. Oxford and New York: Oxford University Press. 606 p.

Schminke H.K. 1981. Adaptation of Bathynellacea (Crustacea, Syncarida) to life in the interstitial ("Zoea Theory”) // Int. Rev. ges. Hydrobiol. Vol.66. No.4. P.575637.

Stiassny M.L.J. 1992. Atavisms, phylogenetic character reversals, and the origin of evolutionary novelties // Neth. J. Zoology. Vol.42. No. 2-3. P.260-276.

Thiemann H. 1984. Is the taxon Harpacticoida monophyletic? // Proceedings of the First International Conference on Copepoda (1982 in Amsterdam). P.47-59.

Vaupel-Klein J.C. 1984. An aberrant P2 in Euchirella messinensis (Copepoda, Calanoida) and the original number of segments in the calanoid swimming leg // Crustaceana. Vol.46. P.110-112.

Vincx M., Heip C. 1979. Larval development and biology of Canuella perplexa T. and A. Scott, 1893 (Copepoda, Harpacticoida) // Cah. Biol. Mar. Vol.20. No.3. P.281-299.

Walossek D. 1993. The Upper Cambrian Rehbachiella and the phylogeny of Branchiopoda and Crustacea // Fossils Strata. Vol.32. P.1-202.

Williamson D.J. 1982. Larval morphology and diversity // L.G. Abele (ed.). The biology of Crustacea, 2. Embryology, morphology and genetics. New York \& London: Academic Press. P.43-110. 